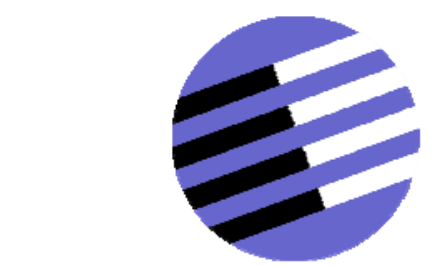

GOVERNANCE AND THE EFFICIENCY

OF ECONOMIC SYSTEMS

GESY

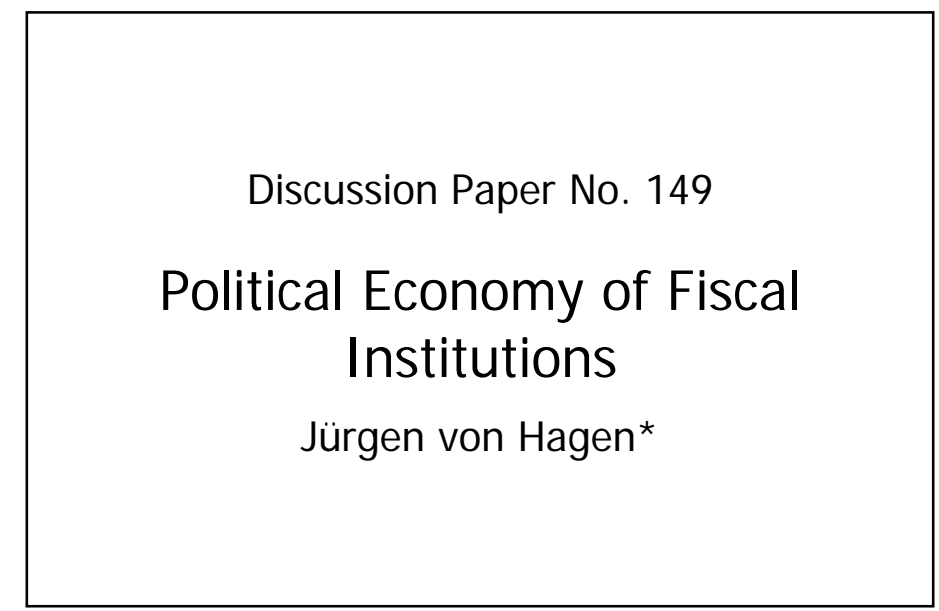

November 2005

*J ürgen von Hagen, ZEI, University of Bonn, Indiana University, and CEPR

Financial support from the Deutsche Forschungsgemeinschaft through SFB/TR 15 is gratefully acknowledged. 


\title{
Political Economy of Fiscal Institutions
}

\author{
Jürgen von Hagen \\ ZEI, University of Bonn, Indiana University, and CEPR
}

Revised, November 2005

\begin{abstract}
We discuss two essential problems of the political economy of public finances: The principal agent problem between voters and elected politicians and the common pool problem arising from the fact that money drawn from a general tax fund is used to pay for policies targeting more or less narrow groups in society. Three institutional mechanisms exist to deal with these problems, ex-ante rules controlling the behavior of elected policy makers, electoral rules creating accountability of and competition among policy makers, and budgeting processes internalizing the common pool externality. We review recent theoretical and empirical research and discuss its implications for research and institutional design.
\end{abstract}

Keywords: electoral systems, fiscal rules, budgeting processes

JEL classification: H11, H61, H62

This paper was prepared as a chapter for the Oxford Handbook on Political Economy. I am grateful to Mark Hallerberg, Barry Weingast, and Donald Wittman for helpful comments and discussions. Financial support by the DFG through SFB TR 15 is gratefully acknowledged. 


\section{Introduction}

The core of public finances is that some people spend other people's money. In democracies, voters delegate the power over public spending and taxes to elected politicians. Two aspects of this are particularly important for the conduct of fiscal policy. The first is the principal-agent relationship between voters (the principals) and politicians (the agents). The second is the common pool problem of public finances (von Hagen and Harden, 1996).

The principal-agent relationship implies that politicians can extract rents from being in office. Voters might wish to limit these rents by subjecting politicians to strict rules. However, the uncertainty and complexity of economic and political developments prohibit the writing of complete contracts. Therefore, the principalagent relation resembles an "incomplete contract" leaving politicians with considerable residual powers (Seabright, 1996; Persson et al., 1997; Persson and Tabellini, 1999a, b, 2000; Tabellini, 2000). The greater these residual powers are, the greater will be the divergence between voter preferences and actual policies. This basic claim has been tested and confirmed by comparing public finances under representative democracy and direct democracy, which gives votes more opportunities to express their preferences and more direct control over politicians, and, hence less residual powers to politicians (Pommerehne 1978, 1990; Matsusaka 1995; Kirchgässner et al 1999; Feld and Kirchgässner 1999; Feld and Matsusaka 2003).

The common pool problem arises when politicians can spend money from a general tax fund on targeted public policies. The fact that the group of those who pay for specific targeted policies (the general tax payer) is larger than the group of those who benefit from them implies a divergence between the net benefits accruing to the targeted groups and the net benefits for society as a whole. This divergence induces the targeted groups and the politicians representing them to demand more spending on such policies than what is optimal for society as a whole. Thus, the common pool problem leads to excessive levels of public spending. Putting the argument into a dynamic context, one can show that it also leads to excessive deficits and government debts (Velasco 1999, von Hagen and Harden 1996.) This tendency for excessive spending, deficits and debt increases with the number of politicians drawing on the same general tax fund, a point empirically confirmed by Perotti and Kontopoulos (1999). Ideological and ethnic divisions or ethno-linguistic and religious fractionalization of societies increase the tendency of people one side to neglect the tax burden falling on the other side, making the common pool problem more severe. Thus, empirical studies showing that such schisms result in higher spending levels, deficits and debt confirm the importance of the common pool problem (Roubini and Sachs 1989; Alesina and Perotti 1995; Alesina et al. 1997; Annett 2000).

The common pool problem also looms large behind vertical fiscal relations within countries. Transfers from the central to local governments imply that residents in one region benefit from taxes paid by residents in other regions. Bailouts of overindebted local governments are a special form of such transfers. Carreaga and Weingast (2000) show how vertical transfers distort local decisions towards excess spending and a bias in favor of public consumption. The studies collected in Rodden et al. (2003) and Fernandez-Arias et al. (forthcoming) confirm the empirical relevance of bailouts in many countries. 
The adverse consequences of the principal-agent problem and the common pool problem can be mitigated by institutions governing the decisions over public finances. Three types of fiscal institutions are particularly relevant in this context: (1) Ex-ante rules such as constitutional limits on deficits, spending or taxes, (2) electoral rules fostering political accountability and competition, and (3) procedural rules of the budget process. Studying the effects of these three types of fiscal institutions has been a very active field of research in the past 15 years, stimulated by the need to reign in excessive spending and deficits in OECD and developing countries alike, and by the European Union's desire to find an adequate set of rules governing national fiscal policies in its monetary union.

This chapter reviews and discusses this research on fiscal institutions. Section 2 deals with ex-ante rules. Section 3 discusses the roles of electoral institutions. Section 4 considers the budget process. Section 5 concludes.

\section{Ex-ante Rules}

We define ex-ante fiscal rules as numerical constraints on certain budgetary aggregates. Prominent examples are the balanced-budget constraints, numerical debt ceilings, and limits on (the growth of taxes and spending that exist in almost all states of the U.S. and most provinces in Canada, and the numerical debt and deficit limits of the European Monetary Union. Historically, such rules were often imposed by taxpayers, who were angry about the spending profligacy of their elected representatives (Eichengreen and von Hagen 1996, Millar 1997) or rising taxes (Alm and Skidmore 1999.) Ex-ante rules are also frequently imposed on sub-national governments to protect the central government against the risk of having to bailout highly indebted sub-national governments with limited revenue sources of their own (von Hagen and Eichengreen, 1996).

There is a fair amount of variation in the scope and strictness of ex-ante rules (see ACIR (1987) and Strauch (1998) for the US, Jones et al. (1999) for Argentine provinces, Hallerberg et al. (2001) for European countries, and von Hagen and Eichengreen (1996) and Stein et al. (1999) for other countries.) At the national level, ex-ante fiscal rules remain fairly rare (see Kennedy and Robbins (2001) and Kopits (2001)). Germany, Italy, Japan, and the Netherlands introduced such rules after World War II to enhance the credibility of their macroeconomic stabilization programs. In the US, the Gramm-Rudman-Hollings legislation of the 1980s is a prominent example of an unsuccessful ex-ante rule. Canada and New Zealand introduced fiscal rules at the national level in the early 1990s, as did the member states of the European Monetary Union. In Switzerland, a constitutional debt limit was voted into effect by public referendum in December 2001.

Ex-ante rules seem straightforward to control politicians and attractive for simplicity and transparency. But how successful are they? Empirical evidence (Strauch, 1998; Eichengreen, 1990; von Hagen, 1991) suggests that US state governments subject to stringent numerical deficit constraints tend to substitute debt instruments not covered by the legal rule for the debt instruments that are, leaving total debt unaffected. Kiwiet and Szakalay (1996) find that state governments subject to more restrictive borrowing constraints tend to substitute municipal debts for state debt. Fatas et al. (2003) find that the deficit limits of the European Monetary Union did not constrain deficits in the large member states effectively. Wolff and von Hagen (2004) show that member states of the European Monetary Union use creative accounting to circumvent the deficit limits. In US states, constitutional expenditure 
limits tend to induce a shift from the (constrained) current budget to the (unconstrained) investment budget (Strauch, 1998). Rueben (1997) and Shadbegian (1996) find no significant effects of tax and expenditure limits on the level of spending in cross-section studies of US states. Controlling for the possible endogeneity of the rules, Rueben (1997) finds that the tax burden is slightly lower in the presence of tax limits. The key insight from this research is that the effectiveness of ex-ante fiscal rules is limited at best, because the rules can be circumvented.

Furthermore, ex-ante limits on sub-national government deficits and debts can create a strategic dilemma for the central government, if the sub-national governments do not own a sufficiently strong tax base. Bordignon (2000) shows that, in the 1970s and 1980s, Italian local governments frequently overran their budgets and turned to the national government for additional transfers, threatening to close down critical public services like hospitals and schools otherwise. Knowing that they could not borrow for legal reasons and had no tax significant sources of their own, the national government had little choice but to give in to their demands. Several of the case studies of local government bailouts in Latin America collected in Fernandez-Arias et al (forthcoming) describe similar strategic behavior by subnational governments. von Hagen and Eichengreen (1996) find that central government debt ratios tend to be higher in countries where sub-national governments are subject to ex-ante borrowing constraints. This suggests that central governments accommodate demands from local governments to borrow on their behalf, exposing the central government to more financial fragility.

Several authors have suggested that ex-ante limits on deficits and debts have beneficial effects on risk premia contained in government bond yields (Goldstein and Woglom 1992; Poterba and Rueben 1999.) However, there may be harmful effects as well. Tight balanced-budget constraints may prevent reforms because governments cannot smooth their fiscal costs over time. Razin and Sadka (2003) illustrate this point in the context of social security reform in an aging society, where the benefits and taxes of a pay-as-you-go system must be scaled back to keep the system viable. To be acceptable to both the current young and old generations, this reform must be financed in part by an increase government debt. With a tight limit on government debt, the reform fails to win the required political support. In this case, the fiscal rules effectively undermines the financial stability of the government, because it focuses too narrowly on current and explicit debt and neglects future fiscal liabilities.

Poterba (1994) shows that states subject to more stringent numerical limits on deficits and debt tend have more pro-cyclical and, hence, less efficient fiscal policies and more macroeconomic volatility. In contrast, Fatas and Mihov (2003) find that exante rules prevent governments from engaging in discretionary policies creating unnecessary macroeconomic fluctuations. The result would be more efficient fiscal policies and less macroeconomic volatility. Fatas and Mihov (2004) provide econometric evidence suggesting that the second effect dominates. Thus, the implications of ex-ante rules for macro economic stability remain an open question.

\section{Political Competition and Accountability}

According to the retrospective-voting paradigm, voters use elections to hold politicians accountable for past performance. They reappoint incumbents, if they find their behavior satisfactory, otherwise, they vote for competing candidates. This suggests that rents can be limited by strict accountability and fierce competition. Political accountability and competition are determined by the rules governing 
political elections. Electoral rules are characterized by district magnitude, electoral formula, and ballot structure. District magnitude relates to the number of representatives elected from each electoral district. Electoral formula translates votes into seats. Ballot structure determines how citizens vote, e.g., they cast votes for individual candidates or they vote for entire party lists.

Different combinations of these three characteristics exist and they frequently do not conform neatly to stylized prototypes. A few tendencies can be identified, however. The combination of small district magnitude, plurality rule and votes cast for individual candidates focuses the election on the personal performance of the candidates, maximizing personal accountability. In contrast, large district magnitude combined with proportional representation and votes cast for party lists focuses the election on the average performance of all candidates on the party list and weakens personal accountability. Thus, one should expect that the scope for extracting political rents from being in office is smaller with small district magnitude, plurality rule, and votes cast for individual candidates.

But electoral rules emphasizing personal accountability also give voters a greater opportunity to reward politicians for channeling general tax funds in their direction. If individual effort rather than average party effort is rewarded, each politician has a greater incentive to fight for policies benefiting his constituency. Furthermore, the winner-take-all structure of electoral outcomes under plurality rule implies that the minimum winning coalition of voters to gain a majority in parliament is smaller than under proportional representation. Plurality rule therefore induces politicians to target small but critical constituencies in individual electoral districts by providing the local public goods and services they demand. In contrast, proportional representation forces political parties to seek the support of broader shares of the electorate and, therefore, induces politicians to favor policies benefiting large groups of voters such as general public goods and welfare programs which benefit voters in many electoral districts (Persson and Tabellini, 2004a; Milesi-Ferretti et al., 2002, Lizzeri and Persico, 2001).

The implications for public finance are threefold. First, by putting a check on rent extraction, electoral rules strengthening personal accountability should lead to lower levels of public spending. Second, proportional representation should lead to higher shares of broad-based welfare programs and general public goods in public spending than plurality rule. Third, both proportional representation and plurality rule contribute to the common pool problem, although they promote different types of targeted policies. As discussed below, the extent to which the common pool problem leads to excessive levels of spending, deficits, and debt depends on the design of the budget process. This implies that empirical tests of the first two implications should control for the prevailing budgetary institutions.

We now turn to the other aspect, competition. The need to gain a large share of votes in a district under plurality rule is an important barrier to entry for small parties. Political newcomers find it difficult to challenge incumbent politicians, because they need a majority to succeed from the start. In contrast, newcomers can win at least a small number of seats in parliament under proportional representation. Political competition is, therefore, more intense under the latter system, particularly when minimum vote thresholds are low. If contestants use the election campaign to identify waste and point to instances of rent-extraction, one can expect more intense competition to lead to less waste and smaller rents. Thus, the consequences of weaker accountability under proportional representation may be compensated by more intense competition. 


\section{Empirical Evidence}

The preceding discussion implies that detailed characterizations are necessary to capture the full details of electoral rules. As a result, one should not expect simple, clear-cut results. Some interesting evidence exists nevertheless. Persson and Tabellini (2004b) find that, in a panel of 90 democracies, countries with plurality rule have smaller governments than countries with proportional representation, and that the differences are economically significant. Persson and Tabellini (2003) find that, in a panel of 60 democracies, all countries expanded the size of government over the 1970 s and 1980s, but countries with plurality rule experienced lower growth of government spending than countries with proportional representation.

Persson, Tabellini, and Trebbi (2003) find that proportional representation is associated with higher levels of corruption than plurality rule. If corruption is a proxy for rents, this is consistent with the theory. Persson and Tabellini (1999b, 2004b) and Milesi-Ferretti (2002) also show that governments elected under plurality rule are characterized by lower shares of spending on general public goods and broad-based welfare programs than those elected under proportional representation.

Hallerberg (2000) argues that Italy's electoral reforms of 1994 were an important factor enabling the country to meet the fiscal requirements of European Monetary Union. Wibbels (2003) finds that, in the 1820 s to 1840 s, governments of US states where political competition was low, had a greater tendency to accumulate large debt burdens than governments in more competitive states. Skilling (2001) reports a similar finding for a set of OECD countries after World War II. Hallerberg and Marier (2004) study a sample of Latina American states and find that the common pool problem is more relevant in countries whose electoral rules focus on personal accountability. In sum, while the existing evidence is scant, it supports the view that electoral rules have important consequences for public spending.

\section{Limiting the Common Pool Problem: The Budget Process}

At the heart of the common-pool problem of public finances is an externality that results from using general tax funds to finance targeted public policies. Individual politicians perceive that an increase in spending on targeted policies will provide their constituencies with more public services at only a fraction of the total cost. The resulting spending and deficit biases can be reduced by inducing politicians to take a comprehensive view of the costs and benefits of their decisions. This is the main role of the budget process in our context. The budget process consists of the formal and informal rules governing budgetary decisions of the executive and legislative branches of government. A centralized budget process contains elements that induce decision makers to internalize the common pool externality by taking a comprehensive view of their decisions. A fragmented budget process fails to do that.

In this context, centralization refers to the internal organization rather than the geographical structure of budgetary decisions. Centralization of the budget process requires that all conflicts between competing claims on public finances are resolved within its scope. Four deviations from this principle result in fragmentation. The first is the use of off-budget funds allowing policy makers to make financial decisions without being challenged by conflicting distributional interests. The second are nondecisions, which make budgetary expenditures dependent on developments exogenous to the budget process, such as the indexation of spending programs and 
open-ended welfare appropriations. Non-decisions degrade the budget process to a mere forecast of exogenous developments. The third deviation occurs when nonfinancial laws can make certain government expenditures compulsory, which implies that budgetary decisions are made outside the budget process. The fourth deviation results from unreported contingent liabilities such as guarantees for the liabilities of public or private enterprises or financial institutions. Contingent liabilities imply that the ex-post distribution of public funds can differ significantly from the distribution negotiated in the budget process.

Transparency is another important prerequisite of centralization. It requires that the budget documents are comprehensive and that expenditures are clearly attributed to the relevant spending making units within the government. Lack of transparency creates opportunities for collusion among self-interested policy makers and prevents decision makers from developing a comprehensive view of the consequences of their decisions.

Budget processes can be proximately divided into four stages, each involving different actors with different roles. The executive planning stage involves the drafting of the budget by the executive. The legislative approval stage includes the process of parliamentary amendments to the budget proposal, which may involve more than one house of parliament. The executive implementation stage covers the fiscal year to which the budget law applies. The ex-post accountability stage involves a review of the final budget documents by a court of auditors or a similar institution checking their consistency with the legal authorization.

Reviewing budget processes in Europe, the US, Latin America and Asia reveals that centralization follows two basic approaches. The first is centralization based on delegation, the second is centralization based on contracts.

With delegation, the rules of the executive planning stage of the budget process lend special authority to a central agent who determines the broad parameters of the budget and enforces them using selective punishments for defecting spending ministers. Typically this agent is the finance minister, who can be expected to take the most comprehensive view of the budget among all members of the executive, and, therefore, to internalize the common pool externality. At the legislative approval stage, the delegation approach lends large agenda-setting powers to the executive. At the implementation stage, centralization requires that the central agent be able to monitor and control the flow of expenditures during the year, to prevent spending departments from overspending their appropriations. Furthermore, centralization puts tight limits on any changes in the budget law during the fiscal year and limits the use of supplementary budgets.

In contrast, the contract approach emphasizes binding budgetary agreements on a set of fiscal targets negotiated among all members of the executive at the onset of the executive planning stage. Here, the bargaining process serves as a mechanism to internalize the common pool externality. In practice, the targets are often derived from medium-term fiscal programs or coalition agreements among the ruling parties. The finance ministry's role under this approach is to evaluate the consistency of the individual departments' spending plans with these limits. Thus, the finance minister has information advantages but no extra strategic powers. At the legislative stage, the contract approach places more weight on the role of the legislature monitoring the faithful implementation of the fiscal targets and less on controlling parliamentary amendments. At the implementation stage, finally, the contract approach resembles the delegation approach in that it requires strong monitoring and control powers of the finance minister. 
It is quite obvious that the delegation approach relies on hierarchical structures within the executive, and between the executive and the legislature, while the contract approach builds on a more even distribution of authorities in government. In democratic settings, hierarchical structures typically prevail within political parties, while relations between parties are more even. This suggests that the institutional choice between the two approaches depends on the number of parties in government. Delegation is appropriate for single-party governments, while the contracts approach is appropriate for multi-party coalition governments (Hallerberg and von Hagen 1999). There are two reasons behind this conjecture.

First, the delegation of strategic powers to the finance minister would create a new principal agent problem for coalition governments. Cabinet members are likely to have very different views on spending priorities and the finance minister could abuse any special powers he has to promote the political interests of his own party at the cost of others. This problem does not arise in one-party governments, where spending ministers can be reasonably sure that the finance minister shares their basic spending preferences.

Second, delegation and contracts use different enforcement mechanisms. Under delegation, the ultimate punishment for a defecting spending minister is his dismissal from office. This punishment is heavy for the individual, but light for the government as a whole. It can be used, if the prime minister has the authority to select and replace cabinet members, which is typically not true in coalition governments. Breaking up the coalition is the ultimate punishment in coalition governments. This punishment is heavy for the entire coalition. Finally, commitment to fiscal targets is per-se much less credible for one-party governments, who can always walk away from the targets with no further consequences.

These different enforcement mechanisms also explain the different relations between the executive and the legislature. When a single ruling party enjoys a majority in parliament, the main concern of the legislative stage is to limit the scope of defections from the budget proposals by individual members of parliament. This can be achieved by limiting the scope of parliamentary amendments to the budget proposal. With multi-party coalitions, in contrast, each party involved in the coalition will want to watch carefully that the executive sticks to the coalition agreement. Therefore, the contract approach typically vests the legislature with more information rights and stronger amendment power than the delegation approach (Hallerberg et al. 2001).

Elections based on plurality rule promote the emergence of two-party systems and one-party majority governments (Duverger, 1954; Taagepera and Shugart, 1989, 1993.) In contrast, proportional representation is consistently characterized by multi-party coalition governments (Lijphart, 1984, 1994; Taagepera and Shugart 1989, 1993). This suggests that countries are more likely to opt for the contract approach, if their elections are based on proportional representation (and low thresholds), while they are more likely to opt for delegation, if their elections based on plurality rule. Hallerberg and von Hagen (1998) and Hallerberg et al (2001) test and confirm this hypothesis for the European Union states. Thus, different electoral rules demand different institutional solutions to the common pool problem.

In presidential systems of government, the president does not rely directly on the legislature for his position as leader of the executive. Voters can, and often do, support a president from one party while denying his party a majority in the legislature. The role of the executive in the budget process is not much different in presidential systems. Since the president typically appoints the members of his administration - with confirmation by the legislature where applicable - the structure 
of the administration lends itself more to a delegation approach than to a contract approach to centralizing the budget process. The relationship between the president and the legislature, however, is often more difficult, since the two are conceived to be more equal political institutions than in parliamentary forms of governments.

As a result, centralization of the budget process in presidential systems emphasizes two institutional dimensions. One is the internal organization of the legislature. Here, centralization can be achieved by creating a strong leadership in parliament, through an elevated position of the speaker and through a hierarchical committee structure. The other dimension regards the relation between the executive and the legislature. The more the constitution puts the two institutions on an equal footing, the more budget agreements between the two must rely on the contract approach.

\section{Empirical Evidence}

The hypothesis that centralization of the budget process leads to lower government deficits and debts has been confirmed empirically in very different geographical and political settings. Von Hagen (1992a) provides evidence from 12 European Union countries showing a significant negative association between the centralization of the budget process and general government deficits and debts relative to GDP. Von Hagen and Harden (1994b) extend and broaden the analysis and confirm the hypothesis that centralization of the budget process is associated with smaller deficits and debts. De Haan and Sturm (1994) work with EU data and show that the hypothesis holds up empirically even when a number of political factors such as the composition and stability of governments is controlled for. Hallerberg and von Hagen $(1998,1999)$ use panel data for 15 EU countries and show that centralization of the budget process goes along with smaller annual budget deficits even when controlling for a number of economic determinants of the budget deficit and other political variables. Country studies for Belgium (Stienlet 2000), Sweden (Molander 2000) and Germany (Strauch and von Hagen 1999) point to the importance of centralization in achieving (or, in the case of Germany losing) fiscal discipline.

Gleich (2002) studies the budget processes in 10 Central and East European countries, an interesting sample since a budget process in the proper sense did not exist under the socialist regime. All ten countries hold elections under various forms of proportional representation. Gleich shows that centralization conforms to the contract approach in these countries and that there is a strong negative association between the degree of centralization of the budget process and the public sector deficits and debts that emerged in the second half of the 1990s. His results are largely confirmed by Yläoutinen $(2004 a, b)$.

Alesina et al (1999) and Stein et al. (1999) use panel data from Latin America to show that centralization of the budget process goes along with lower government deficits. Jones et al. (1999) analyze Argentine provinces and confirm the same hypothesis. Lao-Araya (1997) provides similar results for 11 Asian countries. Strauch (1998) uses data from the 50 US state governments to show that centralization significantly reduces annual budget deficits. Finally, Strauch (1998) and Gleich (2002) show that centralization of the budget process is also associated with smaller levels of government spending, as the common pool argument suggests. Other empirical studies, however, have failed to confirm this aspect of the theory. A suggestive explanation is that the common pool problem implies that actual spending exceeds its efficient level, and that controlling for differences in the efficient 
level of spending is more difficult in cross-country studies than in the context of US state governments or the Central and East European countries.

The possible endogeneity of institutions is an interesting and important issue in this context. Historical experience suggests that governments make efforts to centralize the budget process to overcome sharp fiscal crises. Relevant examples are France in the 1950s (Wildavsky, 1986) and Sweden in the 1990s (Molander, 2000). Studying the imposition of line-item vetos in US state governments, De Figueiredo (2003) finds that fiscal conservatives strengthen the role of the executive in the budget process when they anticipate losing control over the legislature to fiscal liberals. Gleich and von Hagen (2002) find that states in Central and East Europe characterized by greater social cleavages have adopted more centralized budget processes. This suggests that legislatures were willing to relinquish powers anticipating that budgeting would be plagued by the consequences of severe common pool problems otherwise. Hallerberg, Strauch and von Hagen (2001) find that the choice between the delegation and the contracts approach to centralization among EU states confirms their prediction that the former is more adequate for single-party majority governments, while the latter is more adequate for coalition governments. Hallerberg (2004), in a study of EU countries since 1973, argues that countries with more intense political competition are more likely to adopt institutions that address the common pool problem. All these studies indicate that institutional design responds to political factors and circumstances. More work is necessary to understand this interaction better.

\section{Conclusions}

The political economy of fiscal institutions has emerged as a fascinating and lively field of academic research in the last decade. Insights and implications of this research are of considerable practical relevance as they touch on important questions of the design and reform of constitutions, governments, and executive processes.

The research reviewed in this chapter takes the principal-agent relationship between the voter and the politicians and the common-pool property of public funds as the starting points. It strongly suggests that institutional design matters for fiscal performance. It also suggests that different political and constitutional environments demand different institutional solutions to these problems. More research is needed to explore this avenue. Furthermore, the research reviewed here has considered fiscal institutions of different kinds. Constitutional aspects such as electoral rules or the degree of political decentralization seem to be more fundamental than budgetary processes, but the latter should not be ignored. Future research into the fiscal effects of constitutions should pay more attention to controlling for the effects of these lower-level institutions. Furthermore, more research is needed on the endogeneity of constitutional aspects and how the factors than impinge on them affect the effectiveness of lower-level institutions.

\section{References}

Advisory Council for Interstate Relations (ACIR). 1987. "The Effect of Constitutional Restraints on Government Spending." Significant Features of Fiscal Federalism. Washington, D.C. 
Alesina, Alberto, and Roberto Perotti. 1995. "Fiscal Expansions and Adjustments in OECD Countries.” Economic Policy 207-248.

Alesina, Alberto, Reza Baqir, and William Easterley. 1997. Public Goods and Ethnic Divisions. NBER Working Paper No. 6009.

Alesina, Alberto, Ricardo Hausman, Rudolf Hommes, and Ernesto Stein. 1999. "Budget Institutions and Fiscal Performance in Latin America." Journal of Development Economics 59, 253-273

Alm, James, and Mark Skidmore (1999), "Why do Tax and Expenditure Limitations Pass in State Elections?" Public Finance Review 27: 481-510

Annett, Anthony. 2000. Social Fractionalization, Political Instability, and the Size of Government. IMF Working Paper 00/82.

Bordignon, Massima (2000), "Problems of Soft Budget Constraints in Intergovernmental Relationships: The Case of Italy.” Working Paper, Catholic University of Milan

Careaga, Maite, and Barry R. Weingast (2000), "The Fiscal Pact With the Devil: A Positive Approach to Fiscal Federalism, Revenue Sharing, and Good Governance." Working Paper, Stanford University.

De Figueiredo, Rui J. P. (2003), "Endogenous Budget Institutions and Political Insulation: Why States Adopt the Line Item Veto.” Mimeo, UC Berkeley, forthcoming in Journal of Public Economics

De Haan, Jakob, and Jan-Egbert Sturm. 1994. "Political and Institutional Determinants of Fiscal Policy in the European Community." Public Choice 80: 157-172.

Duverger, Maurice. 1954. Political Parties: Their Organization and Activity in the Modern State. New York: Wiley.

Eichengreen, Barry. 1990. “One Money for Europe?” Economic Policy.

Eichengreen, Barry, and Jürgen von Hagen. 1996. "Fiscal Policy and Monetary Union: Federalism, Fiscal Restrictions, and the No-Bailout Rule." In Horst Siebert (ed.), Monetary Policy in an Integrated World Economy. Tübingen: JCB Mohr.

Fatas, Antonio, and Ilhan Mihov (2003), „The Case for Restricting Fiscal Policy Discretion." Quarterly Journal of Economics 118, 1419-1448

Fatas, Antonio, and Ilhan Mihov (2004), "The Macroeconomic Effects of Fiscal Rules in the U.S. States." Mimeo: INSEAD

Fatas, Antonio, Andrew Hughes Hallett, Anne Sibert, Rolf Strauch, and Juergen von Hagen (2003), Stability and Growth in Europe: Towards a Better Pact. Monitoring European Integration 13, London: CEPR

Feld, Lars P., and Gebhard Kirchgässner. 1999. "Public Debt and Budgetary Procedures: Top Down or Bottom Up?” In James Poterba and Jürgen von Hagen (1999)

Feld, Lars P., and John G. Matsusaka (2003), "Budget Referendums and Government Spending: Evidence from Swiss Cantons." Journal of Public Economics 87, 2703-24

Fernandez-Arias, Eduardo, Ernesto Stein, and Jürgen von Hagen (eds.), Subnational Government Bail-outs. Forthcoming.

Gleich, Holger (2002), The Evolution of Budget Institutions in Central and Eastern European Countries. PhD Dissertation, University of Bonn

Gleich, Holger, and Jürgen von Hagen (2002), „The Evolution of budget Institutions. Evidence from Central and East European Countries.” Mimeo, ZEI University of Bonn

Goldstein, Morris, and Geoffrey Woglom (1992), „Market-Based Fiscal Discipline in Monetary Unions: Evidence from the U.S. Municipal Bond Market.“ in: Mathew Canzoneri, Vittorio Grilli, and Paul R. Masson (eds.), Estabilishing a Central Bank: Issues in Europe and Lessons from the US. New York: Cambridge University Press.

Hallerberg, Mark. 2000. "The Importance of Domestic Political Institutions: Why and How Belgium and Italy Qualified for EMU.” ZEI Discussion Paper. ZEI, University of Bonn.

Hallerberg, Mark (2004), Domestic Budgets in a United Europe: Fiscal Governance from the End of Bretton Woods to EMU. Ithaca: Cornell University Press 
Hallerberg, Mark, and Patrik Marier (2004), "Executive Authority, the Personal Vote, and Budget Discipline in Latin American and Caribbean Countries." American Journal of Political Science 48, 571-87

Hallerberg, Mark, and Jürgen von Hagen. 1998. "Electoral Institutions and the Budget Process." In Kiichiro Fukasaku and Ricardo Hausmann (eds.), Democracy, Decentralization, and Deficits in Latin America. Paris: OECD Development Center

Hallerberg, Mark, and Jürgen von Hagen (1999), "Electoral Institutions, Cabinet Negotiations, and Budget Deficits in the EU" in: Jim Poterba and Jürgen von Hagen (1999)

Hallerberg, Mark, Rolf R. Strauch, and Jürgen von Hagen (2001), The Use and Effectiveness of Fiscal Norms and Rules in the EU. Research Report to the Dutch Ministry of Finance. The Hague

Jones, Mark P., Pablo Sanguinetti, and Mariano Tommasi. 1999. "Politics, Institutions, and Public Sector Spending in the Argentine Provinces." In James Poterba and Jürgen von Hagen. 1999.

Kennedy, Suzanne, and Janine Robbins (2001), „The Role of Fiscal Rules in Determining Fiscal Performance." Department of Finance Working Paper 2001-16, Ottawa

Kiewiet, D. Roderick, and Kristin Szakaly. 1996. "Constitutional Limits on Borrowing: An Analysis of State Bonded Indebtedness." Journal of Law, Economics and Organization 12: 62-97.

Kirchgässner, Gebhard, Lars P. Feld, and Marcel R. Savioz. 1999. Die direkte Demokratie. Basel: Helbing and Lichtenhahn.

Kontopoulos, Yianos, and Roberto Perotti. 1999. "Government Fragmentation and Fiscal Policy Outcomes: Evidence from OECD Countries.” In James Poterba and Jürgen von Hagen 1999.

Kopits, George (2001), „Useful Policy Framework or Unnecessary Ornament?“ IMF Working Paper 145

Lao-Araya, Kanokpan. 1997. "The Effect of Budget Structure on Fiscal Performance: A Study of Selected Asian Countries." IMF Working Paper. Washington, D.C.

Lijphart, Arend. 1984. Democracies: Patterns of Majoritarian and Consensus Government in Twenty-One Countries. New Haven: Yale University Press.

Lijphart, Arend. 1994. Electoral Systems and Party Systems: A Study of Twenty-Seven Democracies 1945-1990. Oxford: Oxford University Press.

Lizzeri, Alessandro, and Nicola Persico (2001), "The Provision of Public Goods Under Alternative Electoral Incentives." American Economic Review 91:225-239

Matsusaka, John G. 1995. "Fiscal Effects of the Voter Initiative: Evidence from the Last 30 Years." Journal of Political Economy 103: 587-623.

Milesi-Ferretti, Gian Maria (2000), "Good, Bad, or Ugly? On the Effects of Fiscal Rules With Creative Accounting." IMF Working Paper 00/172, Washington DC

Milesi-Ferretti, Gian Maria, Roberto Perotti, and Massimo Rostagno (2002), "Electoral Systems and Public Spending." Quarterly Journal of Economics 117: 649-657

Millar, Jonathan. 1997. "The Effect of Budget Rules on Fiscal Performance and Macroeconomic Stabilization." Bank of Canada Working Paper 97-15.

Molander, Per (2000), "Reforming Budgetary Institutions: Swedish Experiences." In: Rolf Strauch and Jürgen von Hagen (eds.), Institutions, Politics, and Fiscal Policy. Dordrecht, Kluwer Academic Publishers

Persson, Torsten, and Guido Tabellini. 1999a. "Political Economics and Public Finance." Mimeo. Forthcoming in Alan Auerbach and Martin Feldstein (eds.), Handbook of Public Finance. Amsterdam: North Holland

Persson, Torsten, and Guido Tabellini. 1999b. "The Size and Scope of Government: Comparative Politics with Rational Politicians." European Economic Review 43: 699735

Persson, Torsten, and Guido Tabellini (2003), The Economic Consequences of Constitutions. Cambridge: MIT Press 
Persson, Torsten, and Guido Tabellini (2004a), "Constitutions and Economic Policy." Journal of Economic Perspectives 18:75-98

Persson, Torsten, and Guido Tabellini (2004b), "Constitutional Rules and Fiscal Policy Outcomes." American Economic Review 94:25-45

Persson, Torsten, Gérard Roland, and Guido Tabellini. 1997. "Separation of Powers and Political Accountability." Quarterly Journal of Economics 112: 1163-1202.

Persson, Torsten, Guido Tabellini, and Francesco Trebbi. 2003. "Electoral Rules and Corruption." Journal of the European Economic Association 1: 958-89

Pommerehne, Werner. 1978. "Institutional Approaches to Public Expenditure: Empirical Evidence from Swiss Municipalities." Journal of Public Economics 9: 255-80.

Poterba, James (1994), "State Responses to Fiscal Crises: The Effects of Budgetary Institutions and Politics." Journal of Political Economy 102, 799-82 1

Poterba, James, and Kim S. Rueben (1999), "State Institutions and the US Municipal Bond Market.” In Poterba and von Hagen (1999)

Poterba, James, and Jürgen von Hagen. 1999. (eds.) Fiscal Institutions and Fiscal Performance. Chicago: University of Chicago Press.

Razin, Assaf, and Efraim Sadka (2003), "Privatizing Social Security Under Balanced Budget Constraints: A Political Economy Approach.” Mimeo, Tel Aviv University

Rodden, Jonathan, Gunnar S. Eskelund, and Jennie Litvack (2003), Fiscal Decentralization and the Challenge of the Hard Budget Constraint." Cambridge: MIT Press

Roubini, Nouriel, and Jeffrey D. Sachs. 1989. "Political and Economic Determinants of Budget Deficits in the Industrial Democracies." European Economic Review 33: 903938.

Rueben, Kim (1997), "Tax Limitations and Government Growth: The Effect of State Tax and Expenditure Limits on State and Local Government.” Mimeo: California Institute of Public Policy

Seabright, Paul. 1996. "Accountability and Decentralization in Government: An Incomplete Contracts Model." European Economic Review 40: 61-89 .

Shadbegian, Ronald J. (1996), "Do Tax and Expenditure Limits Affect the Size and Growth of State Government?" Contemporary Economic Policy 14: 22-35

Skilling, David (2001), "Policy Coordination, Political Structure, and Public Debt: The Political Economy of Public Debt Accumulation in OECD Countries since 1960." PhD Dissertation, Harvard University

Stein, Ernesto, Alejandro Grisanti, and Ernesto Talvi. 1999. "Institutional Arrangements and Fiscal Performance: The Latin American Experience." In Poterba and von Hagen. 1999.

Stienlet, Georges( 2000., "Institutional Reforms and Belgian Fiscal Policies in the 90s." In: Rolf Strauch and Jürgen von Hagen (eds.), Institutions, Politics, and Fiscal Policy. Dordrecht, Kluwer Academic Publishers

Strauch, Rolf R. 1998. "Budget Processes and Fiscal Discipline: Evidence from the US States.” Working Paper. Zentrum für Europäische Integrationsforschung Bonn.

Strauch, Rolf R. and Jürgen von Hagen. 1999. "Tumbling Giant: Germany's Experience With the Maastricht Criteria." In David Cobham and George Zis (eds.), From EMS to EMU. London: MacMillan.

Taagepera, Rein, and Matthew Soberg Shugart. 1989. Seats and Votes: The Effects and Determinants of Electoral Systems. New Haven: Yale University Press.

Taagepera, Rein, and Matthew Soberg Shugart. 1993. "Predicting the Number of Parties: A Quantitative Model of Duverger's Mechanical Effect.” American Political Science Review 87(2): 455-464.

Tabellini, Guido. 2000. "Constitutional Determinants of Government Spending." Working Paper IGIER. Bocconi University.

Velasco, Andres. 1999. "Debts and Deficits with Fragmented Fiscal Policymaking." In James Poterba and Jürgen von Hagen. 1999. 
Von Hagen, Jürgen. 1991. "A Note on the Empirical Effectiveness of Formal Fiscal Restraints.” Journal of Public Economics 44: 199-210.

Von Hagen, Jürgen. 1992a. "Budgeting Procedures and Fiscal Performance in the European Communities. Economic Papers 96.

Von Hagen, Jürgen, and Barry Eichengreen. 1996. "Federalism, Fiscal Restraints, and European Monetary Union." American Economic Review 86, May, 134-38.

Von Hagen, Jürgen, and Ian Harden. 1994a. "Budget Processes and Commitment to Fiscal Discipline." European Economic Review 39: 771-779.

Von Hagen, Jürgen, and Ian Harden. 1994b. "National Budget Processes and Fiscal Performance." In European Economy. Reports and Studies 3: 315-418.

Von Hagen, Jürgen, and Ian Harden. 1996. "Budget Processes and Commitment to Fiscal Discipline." IMF Working Paper.

Wibbels, Eric (2003), "Bailouts, Budget Constraints, and Leviathans: Comparative Federalism and Lessons from the Early United States." Comparative Political Studies 36: 475-508

Wildasin, David (1997), "Externalities and Bail-outs: Hard and Soft Budget Constraints in Intergovernmental Fiscal Relations." World Bank Working Paper Washington DC.

Wildavsky, Aaron (1986), Budgeting. Oxford: Transaction Publishers, $2^{\text {nd }}$ edition

Wolff, Guntram, and Jürgen von Hagen (2004), "What Do Deficits Tell us About Debt? Empirical Evidence on Creative Accounting With Fiscal Rules in the EU" CEPR Discussion Paper, London: CEPR

Yläoutinen, S. (2004a), "Fiscal Frameworks in the Centraland Eastern European Countries." Finnish Ministry of Finance, Economics Department Discussion Paper 72

Yläoutinen, S. (2004b), "The Role of Electoral and Party Systems in the Development of Fiscal Institutions in Central and East European Countries." Mimeo: University of Jyväskylä 